\title{
Record of Ellisella paraplexauroides (Anthozoa: Alcyonacea: Ellisellidae) in Italian waters (Mediterranean Sea)
}

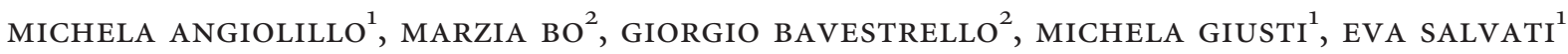 \\ AND SIMONEPIETRO CANESE ${ }^{1}$ \\ ${ }^{1}$ Istituto Superiore per la Protezione e Ricerca Ambientale (ISPRA) (ex ICRAM), Via di Casalotti 300, o0166 Roma, Italy, \\ ${ }^{2}$ Dipartimento di Scienze del Mare, Università Politecnica delle Marche, 60131 Ancona, Italy
}

\begin{abstract}
The occurrence of the candelabrum coral Ellisella paraplexauroides in Italian waters (Sicily Strait, Mediterranean Sea), was documented during a remotely operated vehicle cruise, carried out by ISPRA in May 2010 on-board the RV 'Astrea'. Five specimens were photographed and sampled from 80 to $94 \mathrm{~m}$ depth on the north-east coasts of Pantelleria Island, confirming the distribution of this species in the central Mediterranean Sea. A description of the living colonies and other taxonomic and ecological characteristics is provided.
\end{abstract}

Keywords: Ellisella paraplexauroides, mesophotic zone, remotely operated vehicle exploration, biogeography, Pantelleria Island

Submitted 8 August 2011; accepted 27 September 2011

\section{INTRDロUCTION}

The gorgonians of the genus Ellisella Gray, 1958 are widely distributed from tropical to temperate waters (Fabricius \& Alderslade, 2001; Weinberg \& Grasshoff, 2005). In the Mediterranean Sea, this genus is represented only by one species, Ellisella paraplexauroides Stiasny, 1936 (family Ellisellidae), forming brick-red candlestick colonies, up to $2 \mathrm{~m}$ high (Carpine \& Grasshoff, 1975). The branched colonies have thin, whip-like ramifications arising from a common short stem, heading parallel upwards and dividing dichotomously (Fabricius \& Alderslade, 2001). The unbranched or sparsely branched specimens of this species can be confused with Viminella flagellum (Johnson, 1863) (Carpine \& Grasshoff, 1975; Fabricius \& Alderslade, 2001; Giusti et al., in press), the second ellisellid coral found in the Mediterranean basin, but are easily distinguishable by the sclerites shape and for the red colour, contrasting the whiteyellow appearance of $V$. flagellum.

Ellisella paraplexauroides, similar to $V$. flagellum, has an Atlanto-Mediterranean distribution (Vafidis et al., 1994), however, in contrast with this species, it has been reported in southernmost warm temperate oceanic waters along the western coasts of Africa (Table 1). The first record of E. paraplexauroides was made by Stiasny (1936) from Cap Blanco (Mauritania). Following this, the species was reported in several other Atlantic localities including the coasts of Portugal (Stiasny, 1939a), the Gulf of Cádiz (Arroyo Tenorio et al., 2008; Aguiliar et al., 2010), several sites along the Moroccan coast (Stiasny, 1939b; Grasshoff, 1972, 1992) and in the whole Canary Archipelago (Brito et al., 1984;

Corresponding author:

M. Angiolillo

Email: michela.angiolillo@isprambiente.it
Brito, 1985; Arístegui et al., 1987; Grasshoff, 1992; Ocaña et al., 1992; Bianchi et al., 2000; Brito \& Ocaña, 2004). It also occurs further south along the African coast (apart from the type locality): in Senegal (Grasshoff, 1992; Miralles et al., 1992), Ivory Coast, Ghana, Nigeria and Angola (Grasshoff, 1992). No records have been given so far for the Azores, Madeira Islands, Great Meteor and Josephine Seamounts and Cape Verde Archipelago, where, on the contrary, V. flagellum was found. This led Grasshoff (1972) to suppose that E. paraplexauroides was mainly distributed along the continental coasts, excluding the Canary Islands.

Ellisella paraplexauroides has been firstly reported in the Mediterranean Sea by Stiasny (1940), examining fragments collected along the Algerian and Tunisian coasts (Grasshoff, 1992). Most of the following records within the Mediterranean Sea came from the Gibraltar Strait (Ocaña et al., 2000; Brito \& Ocaña, 2004; Arroyo Tenorio et al., 2008; Torres Gavilá, 2008), Alborán Island (Templado et al., 1986, 2006; Aguiliar et al., 2008), Alborán Sea (Aguiliar et al., 2008) and along the Moroccan coast, in the Chafarinas Islands, where several biological observations were made by SCUBA diving on a rich shallow water population of E. paraplexauroides (López et al., 1996; Peña Cantero \& García Carrascosa, 2002; Castellanos et al., 2003; González García et al., 2005; Aguiliar et al., 2008; Torres Gavilá, 2008; Tocino et al., 2009). A further record was documented from the central Mediterranean Sea, at Sidi Daoud (Tunisia) (Mustapha et al., 2004). Finally, Stiasny (1942) reported E. paraplexauroides also from the Bay of Naples (representing the northernmost record so far) even if, on the basis of the known distribution of the species, this record was generally considered doubtful (Grasshoff, 1972) (Figure 1).

Few data are available concerning biology and ecology of E. paraplexauroides. This has probably resulted from the analysis of small fragments only (Carpine \& Grasshoff, 1975; Ocaña 
Table 1. Biogeographical records for Ellisella paraplexauroides.

\begin{tabular}{|c|c|c|c|}
\hline Locality & Depth (m) & Notes & Reference \\
\hline \multicolumn{4}{|l|}{ Atlantic Ocean } \\
\hline Off Sesimbra, Portugal & - & - & Stiasny, 1939a \\
\hline Gulf of Cádiz & $15-30$ & $\begin{array}{l}\text { Coastline between Chipiona and Rota; on rocks off Huelva } \\
\text { and El Terrón (Gulf of Cádiz); off la Caleta, Cádiz }\end{array}$ & $\begin{array}{l}\text { Arroyo Tenorio et al., 2008; } \\
\quad \text { Aguiliar et al., } 2010\end{array}$ \\
\hline Morocco & - & $\begin{array}{l}1 \text { specimen and various fragments }(\mathrm{MNHN}) ; 2 \text { colonies } \\
(\mathrm{RMNH}, 6136,6142)\end{array}$ & Stiasny, 1939b \\
\hline Asilah, western Moroccan coast & 125 & $\begin{array}{l}\text { Various fragments collected during the Dana Expedition } \\
\quad \text { (Station 1115, ZMUC), SeSam Senckenberg Collection }\end{array}$ & Collected in 1921 \\
\hline Casablanca, Morocco & $110-155$ & $\begin{array}{l}\text { Various colonies collected during the Vanneau Expedition } \\
\quad \text { (Stations } 21,28,37,43, \mathrm{MNHN})\end{array}$ & Collected between 1923 and 1926 \\
\hline Cap Blanc du Nord, Morocco & $100-195$ & $\begin{array}{l}\text { Various fragments collected during the Dana Expedition } \\
\text { (Station 4020, ZMUC), Meteor } 1967 \text { (Station 8-013, } \\
\text { SMF2154), CANCAP Expedition (RMNH 17956) }\end{array}$ & Collected between 1930 and 1967 \\
\hline Cap Cantin, Morocco & 125 & $\begin{array}{l}1 \text { colony and } 2 \text { fragments collected during the Vanneau } \\
\text { Expedition (Station 11, MNHN) }\end{array}$ & Collected between 1923 and 1926 \\
\hline Cap Sim, Morocco & $135-195$ & $\begin{array}{l}\text { Fragments collected during the } 1967 \text { Meteor Expedition } \\
\quad(\text { Station 9-082, SMF 2106, 2155) }\end{array}$ & Collected in 1967 \\
\hline Agadir, Morocco & $110-150$ & $\begin{array}{l}1-2 \text { colonies collected during the Vanneau Expedition } \\
\text { (Stations } 79,91,100,110, \mathrm{MNHN})\end{array}$ & Collected between 1923 and 1926 \\
\hline $\begin{array}{l}\text { Cap Blanco (Cap Corveiro), } \\
\text { Mauritania }\end{array}$ & $30-60$ & $\begin{array}{l}\text { Holotype (2 colonies, Amsterdam Museum), } 1 \text { colony (5973) } \\
\text { and } 4 \text { fragments (5940) in the RMNH; } 1 \text { colony in the } \\
\text { MNHN; fragments collected during the } 1975 \text { Meteor } \\
\text { Expedition (Station 36-107, SMF 6209-10; Station 118, } \\
\text { SMF 3122) }\end{array}$ & $\begin{array}{l}\text { Stiasny, 1936, 1937; collections } \\
\quad 1975\end{array}$ \\
\hline $\begin{array}{l}\text { Punta de Guimar, Las Eras and El } \\
\text { Socorro, Tenerife, Canary } \\
\text { Islands }\end{array}$ & $63-690$ & $\begin{array}{l}\text { Epibiontic Sarcodictyon canariensis encrusting a dead axis of } \\
\text { E. paraplexauroides and other specimens entrapped in } \\
\text { fishing gears. Found especially on the Dendrophyllia } \\
\text { ramea's bottoms }\end{array}$ & $\begin{array}{l}\text { Brito et al., 1984; Brito, 1985; } \\
\text { Arístegui et al., 1987; } \\
\text { Grasshoff, 1992; Ocaña et al., } \\
\text { 1992; Brito \& Ocaña, } 2004\end{array}$ \\
\hline $\begin{array}{l}\text { Puerto del Carmen, Lanzarote, } \\
\text { Canary Islands }\end{array}$ & $\sim 50$ & Visual census and underwater photography & Bianchi et al., 2000 \\
\hline Dakar, Senegal & 45 & Biochemical analysis on E. paraplexauroides's sterols & Miralles et al., 1992 \\
\hline Dakar, Senegal & $45-50$ & $\begin{array}{l}1 \text { colony identified by Kornprobst, } 1986 \text { (SMF 5778), } 1 \\
\text { fragment (MNHN) }\end{array}$ & Collected in 1986 \\
\hline $\begin{array}{l}\text { Ivory Coast (Cap Palmas, Bereby, } \\
\text { Abidjan) }\end{array}$ & $80-100$ & $\begin{array}{l}\text { Various fragments collected during the Orstom Expedition } \\
\text { (MNHN) and the Guinean Trawling Survey (Station 20/6, } \\
\text { MNHN) }\end{array}$ & Collected in 1967 \\
\hline $\begin{array}{l}\text { Ghana (Takoradi Cape Three } \\
\text { Points, Accra, Tema) }\end{array}$ & $33-48$ & $\begin{array}{l}1 \text { colony collected during the Mercator Expedition (MNHN); } \\
5 \text { fragments collected during the Pillsbury Expedition } \\
\text { (Station } 17,27 \text { NMNH Invertebrate Zoology Collection, } \\
85265-85266 \text { ) }\end{array}$ & Collected in 1938 and $1964-1965$ \\
\hline Bight of Benin, Lagos, Nigeria & $82-97$ & $\begin{array}{l}2 \text { fragments collected during the Pillsbury Expedition } \\
\text { (Station 230 NMNH Invertebrate Zoology Collection, } \\
85267 \text { ) }\end{array}$ & Collected in $1964-1965$ \\
\hline Angola (Moita Seca, Ambrizete) & 100 & $\begin{array}{l}1 \text { colony collected during the Atlantique Sud Expedition } \\
\text { (Station 9, MNHN) and } 1 \text { colony identified by Gofas, } 1985 \\
\text { (SMF, 5779) }\end{array}$ & Collected in $1948-1949$ and 1985 \\
\hline \multicolumn{4}{|l|}{ Mediterranean Sea } \\
\hline $\begin{array}{l}\text { Gibraltar Strait (Ceuta, Morocco; } \\
\text { Punta Carnero, Spain) }\end{array}$ & $20-38$ & - & $\begin{array}{l}\text { Ocaña et al., 2000; Brito \& Ocaña, } \\
\text { 2004; Arroyo Tenorio et al., } \\
\text { 2008; Torres Gavilá, } 2008\end{array}$ \\
\hline Alborán Island & $70-140$ & - & Templado et al., 1986, 2006 \\
\hline Chafarinas Islands, Alborán Sea & $15-35$ & $\begin{array}{l}\text { Study through direct surveys of the associated fauna of } \\
\text { E. paraplexauroides: hydroids (Eudendrium rameum, } \\
\text { Filellum sp., Aglaophenia pluma, Antennella secundaria, } \\
\text { Sertularella polyzonias, Clytia linearis, Clytia sp.), } \\
\text { ascidians (Clavelina nana and Pycnoclavella taureanensis), } \\
\text { syllids (Syllis columbretensis, Syllis krohni, Trypanosyllis } \\
\text { coeliaca) and isopods (Paranthura costana and P. } \\
\text { nigropunctata). Some found between mattes of Posidonia } \\
\text { oceanica }\end{array}$ & $\begin{array}{l}\text { López et al., 1996; Peña Cantero \& } \\
\text { García Carrascosa, 2002; } \\
\text { Castellanos et al., 2003; } \\
\text { González-García et al., 2005; } \\
\text { Torres Gavila, 2008; Aguiliar } \\
\text { et al., 2008; Tocino et al., } 2009\end{array}$ \\
\hline Seco de los Olivos, Alborán Sea & $100-200$ & $\begin{array}{l}\text { Detritic bottom together with numerous other anthozoan } \\
\text { corals }\end{array}$ & Aguiliar et al., 2008 \\
\hline
\end{tabular}


Table 1. Continued.

\begin{tabular}{|c|c|c|c|}
\hline Locality & Depth (m) & Notes & Reference \\
\hline Oran and La Calle, Algeria & - & $\begin{array}{l}1 \text { fragment collected by Milne Edwards in } 1836(\mathrm{MNHN}) \\
\text { and } 2 \text { fragments identified by Lacaze-Duthiers in } 1836) \\
(\mathrm{MNHN} \text { and RMNH, 6081) }\end{array}$ & Stiasny, 1940 \\
\hline Tunisia & - & $\begin{array}{l}1 \text { fragment collected during the Univers. Expedition } \\
(\mathrm{MNHN})\end{array}$ & Stiasny, 1940 \\
\hline Algeria and Tunisia & - & $\begin{array}{l}2 \text { colonies about } 1 \mathrm{~m} \text { high and } 1 \text { colony about } 1.7 \mathrm{~m} \text { high } \\
(\mathrm{MNHN})\end{array}$ & Grasshoff, 1992 \\
\hline Sidi Daoud, Tunisia & 47 & $\begin{array}{l}\text { SCUBA-diving surveys. Ellisella sp. reported on a very rich } \\
\text { coastal detritic assemblage }\end{array}$ & Mustapha et al., 2004 \\
\hline Naples & - & 2 fragments (RMNH, 6331) & Stiasny, 1942 \\
\hline Pantelleria Island, Sicily Strait & $80-94$ & 5 specimens $83-173 \mathrm{~cm}$ high on a rocky cliff & Present study \\
\hline
\end{tabular}

et al., 1992) or from investigations focused on the associated fauna (López et al., 1996; Peña Cantero \& García Carrascosa, 2002; Aguiliar et al., 2008; Torres Gavilá, 2008), while in situ observations have been rarely dedicated to this species (Bianchi et al., 2000; Mustapha et al., 2004; Aguiliar et al., 2006, 2008, 2010).

Typical of the circalittoral plain, E. paraplexauroides may show a wide bathymetric distribution ranging from 15 to $690 \mathrm{~m}$ depth, with the shallowest records found mainly in the Mediterranean Sea and the deepest specimens found in the Atlantic Ocean. In particular, it has been reported on the shelf's edge at mesophotic depths between 50 and $150 \mathrm{~m}$ (Templado et al., 1986, 2006; Tocino et al., 2009), but it can also live at bathyal depths, like in the Canary Islands, where it was observed from 63 to $690 \mathrm{~m}$, mainly associated with the assemblages of the scleractinian Dendrophyllia ramea (Linnaeus, 1758) (Brito \& Ocaña, 2004; Arroyo Tenorio et al., 2008). In the Canary Islands it has also been observed that the complexity of the branching pattern and the diameter of the ramifications depends on the type of substrate, as a result the colonies are thinner and sparsely branched when they live on unstable bottoms (Brito \& Ocaña, 2004).

In the Gulf of Cádiz, Gibraltar Strait and Alborán Sea there are some sites where E. paraplexauroides was observed in very shallow waters, respectively $15-30 \mathrm{~m}$ along the coastline of Cádiz (Aguiliar et al., 2010), 15-35 $\mathrm{m}$ depth between the Posidonia oceanica ((L.) Delile, 1813) mattes, at Chafarinas Islands (González García et al., 2005) and 20-25 m depth in Ceuta, along the Moroccan coast (Ocaña et al., 2000; Brito \& Ocaña, 2004).

Quantitative data on the populations of E. paraplexauroides have never been reported in the literature. This species has always been considered very rare and occasional (Grasshoff, 1992; Arroyo Tenorio et al., 2008) and never forming dense meadows, as in the case of $V$. flagellum (Grasshoff, 1971, 1972, 1977). The richest population known so far is the one at Chafarinas Islands (González García et al., 2005). The tallest colonies reported so far, are from the Mediterranean Sea (Grasshoff, 1992).

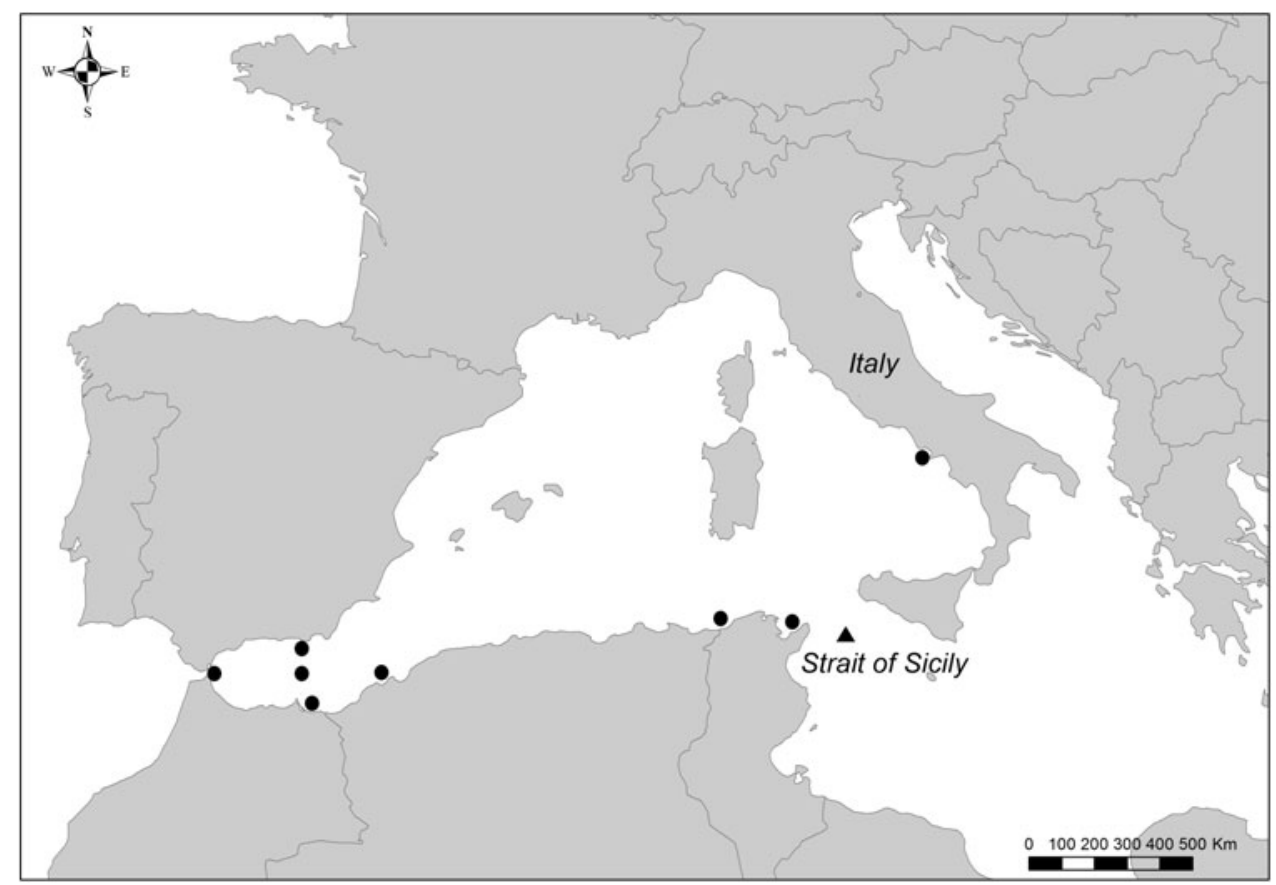

Fig. 1. Map of the geographical distribution of Ellisella paraplexauroides (black dots) in the Mediterranean Sea. Black triangle represents the present record. 
The colonies may host numerous epibionts, especially in their basal part and on larger ramifications. The associated fauna, occupying dead portions of the colonies, is mainly composed of encrusting algae, bryozoans (González García et al., 2005), hydroids (Peña Cantero \& García Carrascosa, 2002), stoloniferans such as Sarcodictyon canariensis Ocaña, Brito \& Nunez, 1992 (Ocaña et al., 1992), and ascidians such as Pycnoclavella taureanensis Brunetti, 1991 and Clavelina nana Lahille, 1890 (Aguiliar, 2004; Tocino et al., 2009). Crustacean isopods of the genus Paranthura (Castellanos et al., 2003) and numerous species of polychaetes (López et al., 1996; Torres Gavilá, 2008) are the main components of the vagile fauna. The number of colonies with epibionts or dead colonies of E. paraplexauroides tends to decrease depending on the depth (Tocino et al., 2009).

The aim of this paper is to provide the first detailed record of E. paraplexauroides for the Italian waters. Moreover, some remarks on its distribution, biology and ecology are given on the basis of remotely operated vehicle (ROV) video and photographic samplings and specimens collection.

\section{MATERIALS AND METHDDS}

The Island of Pantelleria lies along the continental rift system of the Sicily Strait (central Mediterranean Sea). It consists exclusively of volcanic rocks (Villari, 1974) and the entire area is subjected to intensive volcano-tectonic activity. The structural setting of the island is specified by faults and fractures that follow the regional north-west-south-east and north-east-south-west trends (Civetta et al., 1988).

The study site, named Cala Caruscia (locality Punta Spadillo) $\left(36^{\circ} 49.139^{\prime} \mathrm{N} 12^{\circ} 01.537^{\prime} \mathrm{E}\right)$, is located on the northeast side of the island (Figure 2) and was explored through a ROV survey conducted in May 2010 on-board the RV 'Astrea'. The site is characterized by inclined rocky walls

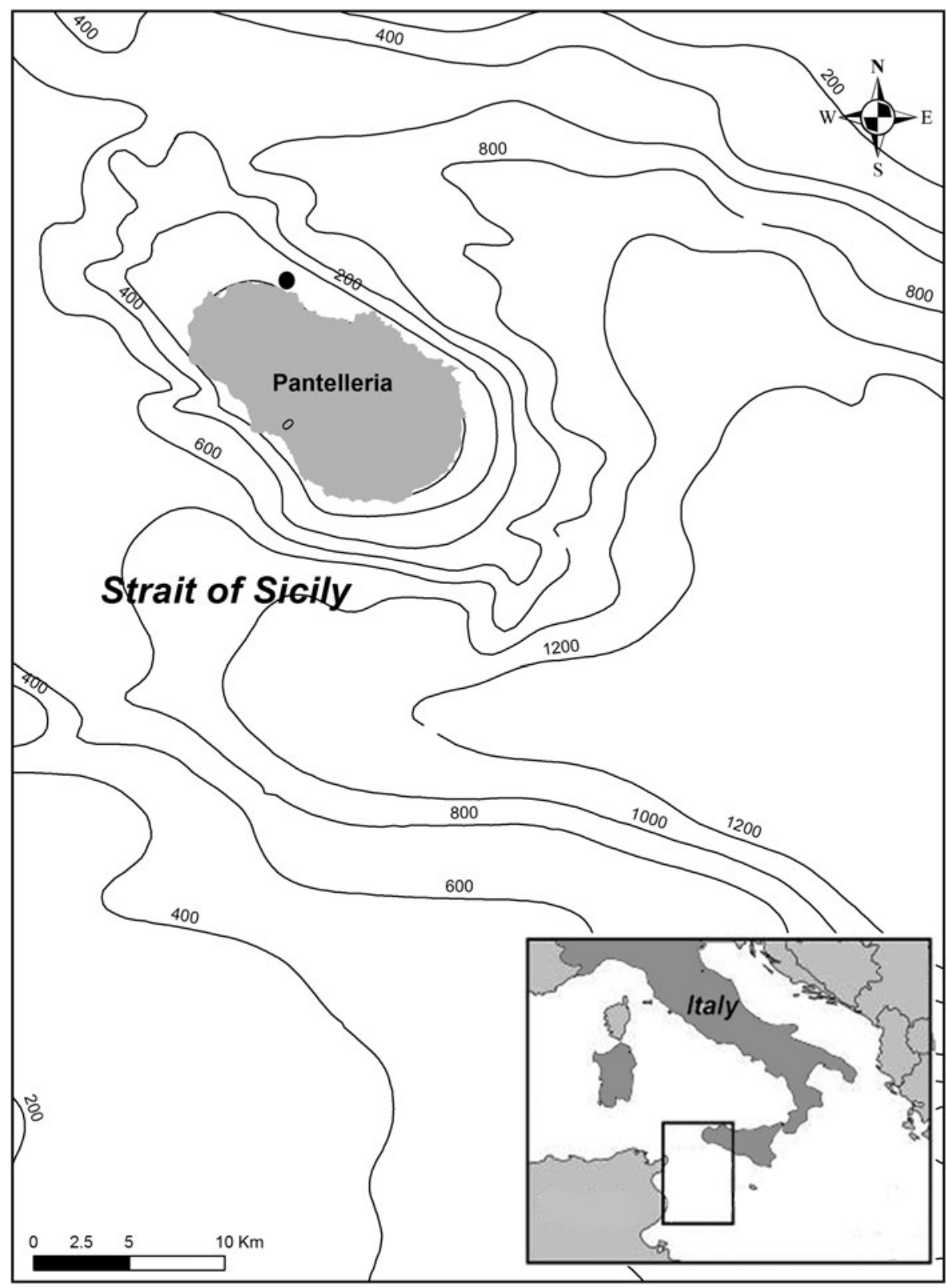

Fig. 2. Map of the sampling area (black dot) on the north-east coast of Pantelleria Island (Sicily Strait). 
down to about $200 \mathrm{~m}$ depth with the bottom first turning into heavily silted rocky boulders and then ending in a gently inclined soft-bottom slope.

The ROV 'Polluce' was equipped with a digital camera (Nikon D80, 10 megapixel), an underwater strobe (Nikon SB 40o), a high definition video camera (Sony $\mathrm{HDR}_{-} \mathrm{HC}_{7}$ ) and a 3-jaw grabber (SeaBotix Inc.) to take samples. Additionally, it had a depth sensor, a compass, and three parallel laser beams $10 \mathrm{~cm}$ apart used as a reference scale to assist the observers in estimating: frame area, sizes (height and width) and branching pattern of what was photographed using the software ImageJ, (Brazeau \& Lasker, 1988). Colonies of Ellisella paraplexauroides were photographed in the mesophotic zone, between 80 and $94 \mathrm{~m}$ depth. Photographs were then analysed to describe the general morphology of the coral colonies and their in vivo appearance. Direct sampling of one specimen was carried out for the species description. Sclerites were analysed with scanning electron microscopy (SEM) after dissolving the coenenchyme in sodium hypochlorite and lastly, a fragment fixed in 95\% ethanol was used for the morphological analysis of polyps carried out with SEM and stereomicroscope.

\section{RESULTS}

The coral community of Pantelleria Island is mainly composed of a mixed assemblage of three-dimensional anthozoans. The dominant species up to $80 \mathrm{~m}$ depth are the gorgonians Paramuricea clavata (Risso, 1826), Eunicella cavolinii (Koch, 1887), Corallium rubrum (Linnaeus, 1758) and, occasionally, the zoanthid Savalia savaglia (Bertoloni, 1819). Sparse colonies of the black coral Antipathella subpinnata (Ellis \& Solander, 1786) were observed around $100 \mathrm{~m}$ depth, while the gorgonians Viminella flagellum and Swiftia pallida Madsen, 1970 were typically distributed in the deepest depth range, below $130 \mathrm{~m}$ depth (Giusti et al., in press). In total, five red brick colonies of Ellisella paraplexauroides were found scattered on the explored hard substrate (Figure $3 \mathrm{~A}-$ D), between 80 and $94 \mathrm{~m}$ depth.

Colonies were anchored to the substrata with a large basal plate, about $10 \mathrm{~cm}$ wide, sometimes covered by fine sediments and other organisms such as sponges or encrusting algae (Figure $3 \mathrm{~A}$ ). The common stem arising from the plate was about $15 \mathrm{~cm}$ long and showed a $2-3 \mathrm{~cm}$ wide basal diameter, not bearing polyps. Observed colonies reached considerable dimensions, from 83 to $173 \mathrm{~cm}$ in height $(130 \pm 35 \mathrm{~cm}$ average) and from 12 and $42 \mathrm{~cm}$ in width $(25 \pm 12 \mathrm{~cm}$ average), being taller than larger because of the typical upward arrangement of their branches (Figure $3 \mathrm{~A}-\mathrm{D})$. The colonies could show up to 30 terminal branches (basal diameter around $3 \mathrm{~mm}$ ).

Only one colony showed the basal portion of some branches partially dead (Figure $3 \mathrm{D}$ ). The naked skeleton was covered by numerous hydroids (unidentified sertularids and eudendrids entrapping a notable quantity of sediment), a colony of Paramuricea clavata, the polychaete Filograna sp. and various encrusting sponges and bryozoans.

During the ROV survey, a sample $35 \mathrm{~cm}$ long was collected from a sparsely branched colony $110 \mathrm{~cm}$ high. Coenenchyme was red, while polyps, monomorphic and highly contractile, were crowded, cylindrical and whitish. Underwater images showed extended polyps characterized by tentacles almost half the length of the calyxes (Figure ${ }_{3} \mathrm{E}$ ). Along the studied apical portion, polyps were arranged in a few longitudinal rows. However, photographs showed multiple rows of calyxes in the most basal parts of the colonies, as already reported in previous descriptions (Grasshoff, 1972; Carpine \& Grasshoff, 1975). Polyps emerged from the branches with a sharp inclination and could show a different orientation when compared to the main stem (Figure $3 \mathrm{~F}$ ). Calyxes (up to $1.5 \mathrm{~mm}$ high) (Figure ${ }_{3} \mathrm{E}, \mathrm{F}$ ) were characterized by a thin calyx wall. When contracted, the polyps formed knobs on the surface of the branches.

Surface sclerites were orange-yellow, while subsurface ones were almost colourless (Figure $3 \mathrm{G}$ ). Sclerites included several types (Figure $3 \mathrm{H}$ ): symmetrical double heads and thick capstans (up to $50 \mu \mathrm{m}$ high) (Figure $3 \mathrm{Ha}-\mathrm{b}$ ) were densely packed on the surface of the coenenchyme; thick highly tuberculated capstans (between 60 and $70 \mu \mathrm{m}$ high) (Figure $3 \mathrm{Hc}$ ) were organized in the subsurface of the coenenchyme; spindles (between 60 and $80 \mu \mathrm{m}$ high) were found in the wall of calyxes (Figure $3 \mathrm{Hd}-\mathrm{e}$ ); and $50 \mu \mathrm{m}$ high rods with few tubercles were found in the pharynx of the anthocodiae (Figure $3 \mathrm{Hf}-\mathrm{g}$ ). Sizes of the sclerites were slightly smaller than what has already been reported for some Atlantic specimens (Carpine \& Grasshoff, 1975), but quite similar to that reported for the Canary Islands (Brito \& Ocaña, 2004).

\section{DISCUSSIDN}

The present record of Ellisella paraplexauroides adds a new species of alcyonacean to the Italian fauna (Morri et al., 2008) (which now accounts for 27 species) and confirms the presence of this species in the central Mediterranean Sea. This record represents also the most eastern report of $E$. paraplexauroides in the Mediterranean basin. The ROV observations on the small population found in the mesophotic zone of Pantelleria Island confirm previous data regarding size, colour, branching pattern and associated fauna (Grasshoff, 1972; Carpine \& Grasshoff, 1975; Arroyo Tenorio et al., 2008). The colonies observed in Pantelleria are also some of the tallest reported in the literature.

Pantelleria Island is situated in a unique area of the Mediterranean Sea, both from the oceanographic and topographic point of view, leading ultimately to an important role in the composition of the benthic fauna (Manzella et al., 1988; Greenpeace International, 2009). In the Sicily Strait, representing the connection between the eastern and western basins of the Mediterranean Sea, two water layers have been observed. The most superficial is composed of the surface Atlantic Waters (AW), running eastward, while the deepest one by the Levantine Intermediate Waters (LIW) flowing in the opposite direction, down to about $500 \mathrm{~m}$ (Napolitano et al., 2003). The particular hydrographic conditions of this area probably favour the presence of rich benthic communities of filter-feeding organisms (Bianchi \& Morri, 2000).

Ellisella paraplexauroides is a typical AtlantoMediterranean species with a wide bathymetric distribution range. The superficial variations in temperature of the Mediterranean waters probably confine this species below $50 \mathrm{~m}$ depth in the Sicily Strait, although some populations were locally recorded at very shallow depths $(15-35 \mathrm{~m}$ in 

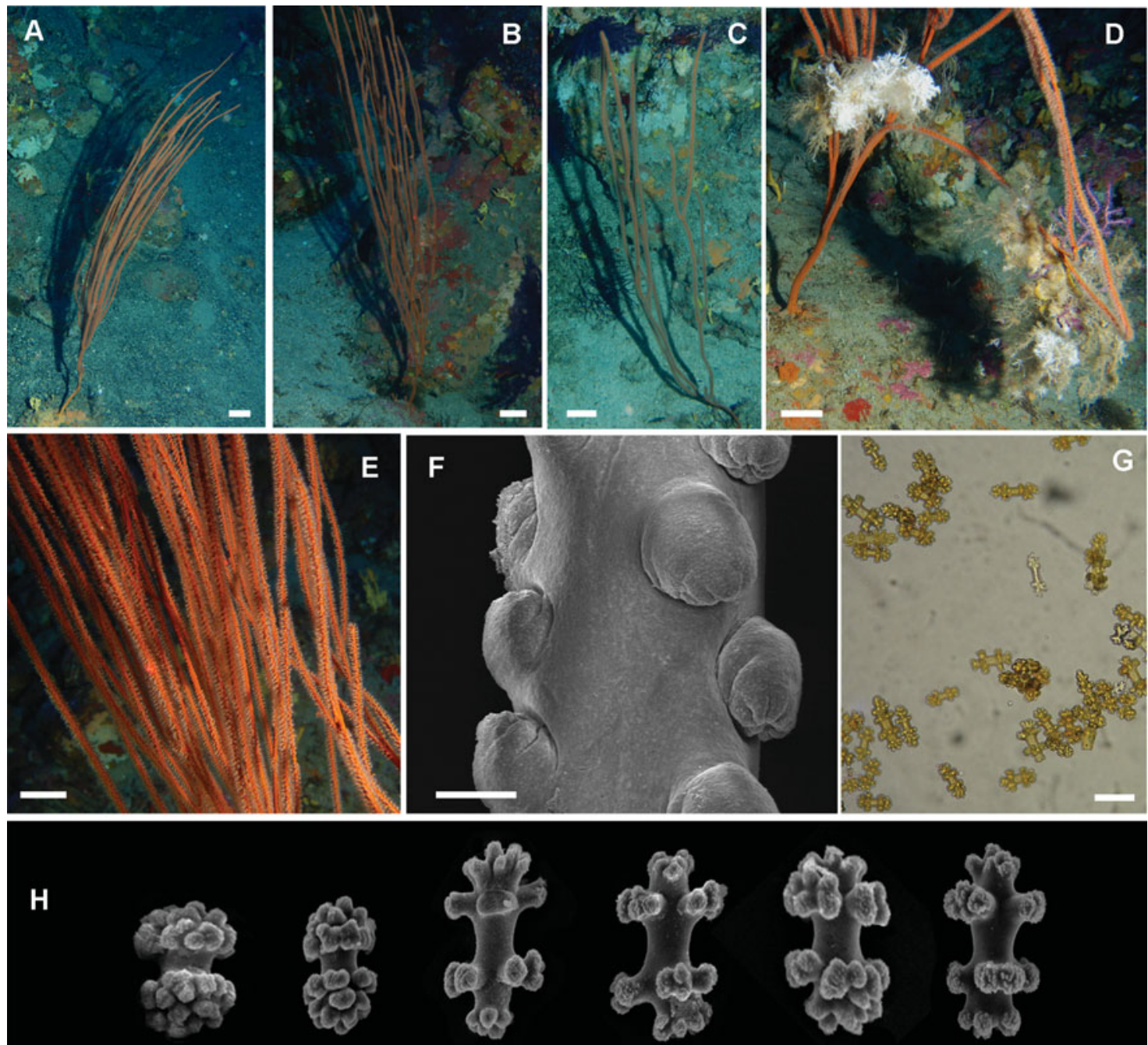

a

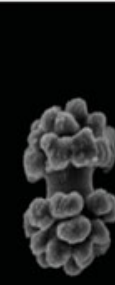

b
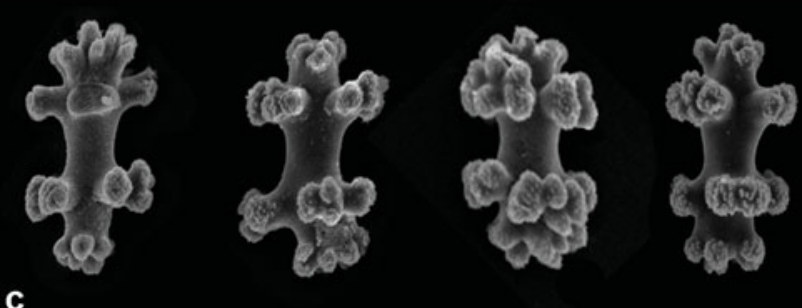

C

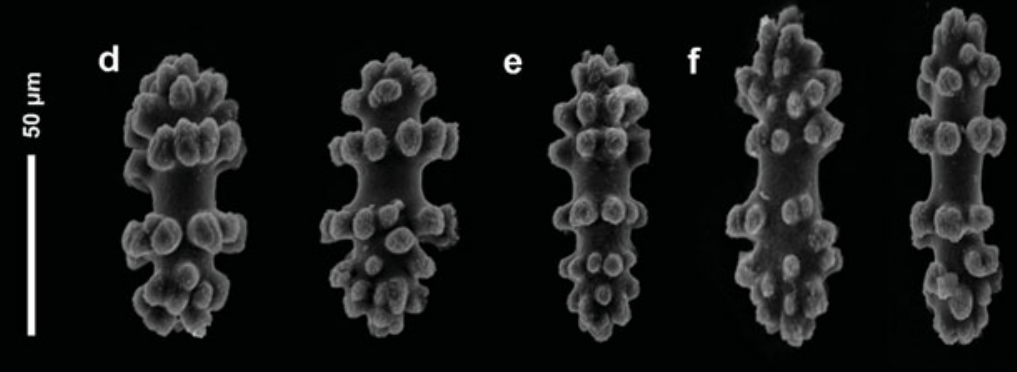

g
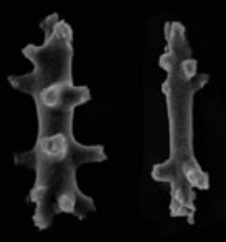

Fig. 3. Ellisella paraplexauroides from Pantelleria Island. (A-D) Underwater photographs of E. paraplexauroides. Occasionally, colonies can be colonized by sessile organisms (Figure D); (E) expanded polyps of a living colony; (F) scanning electron microscopy image of the arrangement of calyxes on the apical portion of a branch; $(\mathrm{G})$ stereomicroscope photograph of the sclerites, both yellow coloured and colourless; $(\mathrm{H})$ sclerites of E. paraplexauroides composed of: a, double head from the superficial layer of coenenchyme; b, thick capstan; $c$, thick capstans with high tubercles; d, girdle spindles; e, slender girdle spindle; f, long rods from the deeper layer of the coenenchyme and from calyxes; g, rods from the pharynx. Scale bars: A-E, $10 \mathrm{~cm} ; \mathrm{F}, 1 \mathrm{~mm} ; \mathrm{G}, 50 \mu \mathrm{m}$.

the Gulf of Cádiz, Strait of Gibraltar and the Alborán Sea) (Arroyo Tenorio et al., 2008).

The scattered distribution of E. paraplexauroides in the explored area was observed in a limited depth range, being the species confined below the distribution limit of the most common gorgonians (Paramuricea clavata and Eunicella cavolinii) and above the distribution range of Viminella flagellum (Giusti et al., in press). Although this species is occasionally considered as characterizing a facies (Gulf of Cádiz,
Atlantic Ocean) (Aguiliar et al., 2010), it never occurs in dense monospecific meadows and can be considered an occasional element in the lower fringe of the circalittoral assemblage.

The recorded susceptibility of E. paraplexauroides to epibiosis may be enhanced by mechanical injuries of the coenenchyme, as already suggested for other deep Mediterranean corals (Tocino et al., 2009). Commercial fishing activities, for example through long-line fishing, 
directly damage these corals that are particularly vulnerable because of their arborescent morphology, fragile construction and the general slow growth rate (Bavestrello et al., 1997; Mortensen \& Buhl-Mortensen, 2004; Bo et al., 2009).

It is well known that assemblages of colonial anthozoans represent biodiversity hotspots (Mortensen \& Buhl-Mortensen, 2004; Ballesteros, 2006; Bo et al., 2009; Cerrano et al., 2010), adding three-dimensional complexity to the habitat and commonly housing a rich associated fauna as well as a great abundance of fish (Tsounis at al., 2006; Mortensen et al., 2008). In the Mediterranean Sea, these communities have been studied mainly in shallow waters, and few data are available for deep environments (Bo et al., 2009, 2010, 2011; Gori et al., 2010).

The complex structure and richness of species of the assemblages hosting E. paraplexauroides, together with their vulnerability to human activities, should motivate the decision of including them within the Mediterranean species and habitat list of conservational relevance.

\section{ACKDWLEDGEMENTS}

We thank the crew members of the RV 'Astrea' for their precious help and work. This work was financed by Italian Ministry of the Environment, Land and Sea Protection.

\section{REFERENCES}

Aguiliar R. (2004) The corals of the Mediterranean. Oceana, Fundación Biodiversidad, $86 \mathrm{pp}$.

Aguiliar R., Pardo E., Cornax M.J., García S. and Ubero J. (2010) Doñana and the Gulf of Cadiz. Marine protected area expansion proposal. Oceana, Fundación Biodiversidad, 8o pp.

Aguiliar R., Pastor X. and Pablo M.J. de (2006) Habitats in danger. Oceana, Fundación Biodiversidad, 83 pp.

Aguiliar R., Torriente A. de la and García S. (2008) Propuesta de áreas marinas de importancia ecológica: Atlantico sur y Mediterraneo español. Oceana, Fundación Biodiversidad, 132 pp.

Arístegui J., Brito A., Cruz T., Bacallado J.J., Barquin J., Nunez J. and Perez-Dionis G. (1987) El poblamiento de los fondos de Dedrophyllia ramea (Antozoa: Scleractinia) en las Islas Canarias. Cuadernos Marisqueros Publicación Técnica 11, 163-181.

Arroyo Tenorio M.C., Domenech A.B., Lampreave D.M. and López-González P.J. (2008) Ellisella paraplexauroides Stiasny, 1936. In Barea-Azcón J.M., Ballesteros-Duperón E. and Moreno D. (eds) Libro rojo de los invertebrados de Andalucía. 4 Tomos. Sevilla: Consejería de Medio Ambiente, Junta de Andalucía, pp. 239-242.

Ballesteros E. (2006) Mediterranean coralligenous assemblages: a synthesis of present knowledge. Oceanography and Marine Biology: an Annual Review 44, 123-195.

Bavestrello G., Cerrano C., Zanzi D. and Cattaneo-Vietti R. (1997) Damage by fishing activities to the gorgonian coral Paramuricea clavata in the Ligurian Sea. Aquatic Conservation: Marine and Freshwater Ecosystems 7, 253-262.

Bianchi C.N., Harounc R., Morri C. and Wirtz P. (2000) The subtidal epibenthic communities off Puerto del Carrnen (Lanzarote, Canary Islands). Life and Marine Sciences 2, 145-155.
Bianchi C.N. and Morri C. (2000) Marine biodiversity of the Mediterranean Sea: situation, problems and prospects for future research. Marine Pollution Bulletin 40, 367-376.

Bo M., Bavestrello G., Canese S., Giusti M., Salvati E., Angiolillo M. and Greco S. (2009) Characteristics of a black coral meadow in the twilight zone of the central Mediterranean Sea. Marine Ecology Progress Series 397, 53-61. [Special Theme Section: Conservation and management of deep sea corals and coral reefs.]

Bo M., Bavestrello G., Canese S., Giusti M., Angiolillo M., Cerrano C., Salvati E. and Greco S. (2010) Coral assemblages off the Calabrian Coast (South Italy) with new observations on living colonies of Antipathes dichotoma. Italian Journal of Zoology. doi: 10.1080/ 11250001003652619 .

Bo M., Bertolino M., Borghini M., Castellano M., Covazzi Harriague A., Di Camillo C.G., Gasparini G.P., Misic C., Povero P., Schroeder K. and Bavestrello G. (2011) Characteristics of the mesophotic megabenthic assemblage of the Vercelli Seamount (North Tyrrhenian Sea). PLoS-One 6, e16357.

Brazeau D.A. and Lasker H.R. (1988) Inter and intraspecific variation in gorgonian colony morphology: quantifying branching patterns in arborescent animals. Coral Reefs 7, 139-143.

Brito A. (1985) Estudio taxonomico, ecologico y biogeografico de los Antozoos de la region litoral de las islas Canarias. $\mathrm{PhD}$ thesis. Universidad de la Laguna, Islas Canarias, España.

Brito A., Cruz T., Moreno E. and Pérez J.M. (1984) Fauna marina de las Islas Canarias. In Bacallado J.J. (ed.) Fauna marina y terrestre del Archipiélago Canario. Las Palmas de Gran Canaria: Edirca, pp. $42-65$.

Brito A. and Ocaña O. (2004) Corales de las Islas Canarias. Antozoos con esqueleto de los fondos litorales y profundos. La Laguna: Francisco Lemus Editor.

Carpine C. and Grasshoff M. (1975) Les gorgonaires de la Méditerranée. Bulletin de l'Institut Océanographique 71, 1-140.

Castellanos C., Hernández-Vega S. and Junoy J. (2003) Isópodos marinos (Crustacea: Isopoda) de las islas Chafarinas (Mediterráneo occidental). Boletin del Instituto Español de Oceanografia 19, 219-233.

Cerrano C., Danovaro R., Gambi C., Pusceddu A., Riva A. and Schiaparelli S. (2010) Gold coral (Savalia savaglia) and gorgonian forests enhance benthic biodiversity and ecosystem functioning in the mesophotic zone. Biodiversity and Conservation 19, 153-167.

Civetta L., Cornette Y., Gillot P.Y. and Orsi G. (1988) The eruptive history of Pantelleria (Sicily Channel) in the last 50 ka. Bulletin of Volcanology 50, 47-57.

Fabricius K. and Alderslade P. (2001) Soft corals and sea fans: a comprehensive guide to the tropical shallow water genera of the central-west Pacific, the Indian Ocean and the Red Sea. Townsville, QL: Australian Institute of Marine Science.

Giusti M., Bo M., Bavestrello G., Angiolillo M., Salvati E. and Canese S. (in press) Record of Viminella flagellum (Alcyonacea: Ellisellidae) in Italian waters (Mediterranean Sea). Marine Biodiversity Records.

González García J.A., García Peña H. and Bueno del Campo I. (2005) Especies singulares y protegidas de la flora y fauna de Melilla e islas Chafarinas. Melilla: Fundación Gaselec.

Gori A., Rossi S., Berganzo E., Pretus J.L., Dale M.R.T. and Gili J.M. (2010) Spatial distribution patterns of the gorgonians Eunicella singularis, Paramuricea clavata, and Leptogorgia sarmentosa (Cape of Creus, Northwestern Mediterranean Sea). Marine Biology 158, $143-158$.

Grasshoff M. (1971) Infraspezifische variation und isolierte Populationen der Hornkoralle Ellisella flagellum (Cnidaria: Anthozoa: Gorgonaria). Meteor Forschungsergen-Ergebnisse 10, 65-72. 
Grasshoff M. (1972) Die Gorgonaria des östlichen Nordatlantik und des Mittelmeeres. I. Die Familie Ellisellidae (Cnidaria: Anthozoa). Meteor Forschungsergen-Ergebnisse 10, 73-87.

Grasshoff M. (1977) Die Gorgonarien des östlichen Nordatlantik und des Mittelmeeres. III. Die Familie Paramuriceidae (Cnidaria, Anthozoa). Meteor Forschungsergen-Ergebnisse 27, 5-76.

Grasshoff M. (1992) Die Flachwasser-Gorgonarien von Europa und Westafrica (Cnidaria, Anthozoa). Courier Forschungsinstitut Senckenberg 149, 1-135.

Greenpeace International (2009) High Seas Mediterranean Marine Reserves: a case study for the Southern Balearics and the Sicilian Channel. CBD's Expert workshop on scientific and technical guidance on the use of biogeographic classification systems and identification of marine areas beyond national jurisdiction in need of protection. Ottawa, September-October, 2009, 58 pp.

López E., San Martín G. and Jiménez M. (1996) Syllinae (Syllidae, Annelida, Polychaeta) Chafarinas lslands (Alborán Sea, W Mediterranean). Miscellania Zoologica 19, 105-118.

Manzella G.M.R., Gasparini G.P. and Astraldi M. (1988) Water exchange between the eastern and western Mediterranean through the Sicily Strait. Deep-Sea Research 35, 1021-1035.

Miralles J., Galonnier R., Njinkoue J.M., Samb A., Gaydou E. and Kornprobst J.M. (1992) Sterol composition of some gorgonians from the Senegalese coast. Comparative Physiology and Biochemistry 103B, 1039-1041.

Morri C., Esposito F. and Pessani D. (2008) Anthozoa. Checklist della flora e della fauna dei mari italiani (Parte I). Biologia Marina Mediterranea 15, 92-101.

Mortensen P.B. and Buhl-Mortensen L. (2004) Distribution of deepwater gorgonian corals in relation to benthic habitat features in the Northeast Channel (Atlantic Canada). Marine Biology 144, $1223-1238$.

Mortensen P.B., Buhl-Mortensen L., Gebruk A.V. and Krylova E.M. (2008) Occurrence of deep-water corals on the Mid-Atlantic Ridge based on MAR-ECO data. Deep-Sea Research Part II 55, 142-152.

Mustapha K.B., Afli A., Hattour A. and El Abed A. (2004) Sessile megabenthic species from Tunisian littoral sites. MedSudMed Technical Documents 2, 1-16.

Napolitano E., Sannino G., Artale V. and Marullo S. (2003) Modeling the baroclinic circulation in the area of the Sicily channel: the role of stratification and energy diagnostics. Journal of Geophysical Research $108,1-21$.

Ocaña A., Sánchez Tocino L., López González S. and Viciana Martín F. (2000) Guía Submarina de Invertebrados no Artrópodos. Granada: Comares Editor.

Ocaña O., Brito A. and Nuñez J. (1992) A new species of Sarcodyction (Anthozoa: Stolonifera) from Tenerife, Canary Islands. Zoologische Mededelingen 66, 423-428.

Peña Cantero A.L. and García Carrascosa A.M. (2002) The benthic hydroid fauna of the Chafarinas Islands (Alborán Sea, western Mediterranean). Zoologische Verhandelingen 337, 1-180.

Stiasny G. (1936) Diagnosen einiger neuer Gorgonarien-Arten von Cap Blanco (Westafrika). Zoologische Anzeitung, Leipzig 113, 201- 206.
Stiasny G. (1937) Gorgonaria von Cap Blanco, gesammelt von Dr. Th. Monod. Temminckia 2, 297-316.

Stiasny G. (1939a) Gorgonaria von Portugal. Arquivo Histórico do Museu Bocage 10, 15-38.

Stiasny G. (1939b) Gorgonaires du Maroc (Côte Atlantique). Collection rassemblée par R.Ph. Dollfus. Bulletin de la Société des Sciences Naturelles de Maroc 19, 119-149.

Stiasny G. (1940) Gorgonides et Alcyonides des collections du Muséum National d'Histoire Naturelle (Première Partie). Archives du Musée $16,109-145$.

Stiasny G. (1942) Alcyonaria und Gorgonaria aus dem Golf von Neapel. Pubblicazioni della Stazione Zoologica di Napoli 19, 1-47.

Templado J., Calvo M., Moreno D., Flores A., Conde F., Abad R., Rubio J., López-Fé C.M. and Ortiz M. (2006) Flora y fauna de la reserva marina y reserva de pesca de la Isla de Alborán. Madrid: Secretaría General de Pesca Marítima MAPA y Museo Nacional de Ciencias Naturales CSIC.

Templado J., Garcia Carrascosa M., Baratech L., Capaccioni R., López Ibor A., Silvestre R. and Masso C. (1986) Estudio preliminar de la fauna asociada a los fondos coralígenos del mar de Alborán (SE de España). Boletin del Instituto Español de Oceanografia 3, 93-104.

Tocino L.S., Barahona M.M., Barranco C.N. and Velasco C.G. (2009) Informe de la campaña realizada en el Refugio Nacional de Caza de las Islas Chafarinas los días o7 al 26 de octubre de 2009. Documentos de interés científico-técnico y divulgativos relacionados con las Islas Chafarinas. Ministerio de Medio Ambiente y Medio Rural y Marino, 18 pp. http://www.mma.es/secciones/el_ministerio/organismos/oapn/ pdf/chaf_articulo26.pdf

Torres Gavilá F.J. (2008) Estudio faunístico, ecológico y ambiental de la fauna de anélidos poliquetos de sustratos sueltos de las Islas Chafarinas (Mar de Alborán, SW Mediterráneo). València: Universitat de València Servei de Publicacions.

Tsounis G., Rossi S., Aranguren M., Gili J.M. and Arntz W. (2006) Effects of spatial variability and colony size on the reproductive output and gonadal development cycle of the Mediterranean red coral (Corallium rubrum L.). Marine Biology 148, 513-527.

Vafidis D., Koukouras A. and Voultsiadou-Koukoura E. (1994) Octocoral fauna of the Aegean Sea with a check list of the Mediterranean species: new information, faunal comparisons. Annales de l'Institut Océanographique, Paris 70, 217-229.

Villari L. (1974) The island of Pantelleria. Bulletin of Volcanology 38, $680-724$.

and

Weinberg S. and Grasshoff M. (2005) Gorgonias. In Hofrichter R. (ed.) El Mar Mediterraneo. Fauna, Flora, Ecologia. II/1. Guia Sistematica $y$ de Identificacion. Ediciones Omega, pp. 428-443.

\section{Correspondence should be addressed to:}

M. Angiolillo

ISPRA (ex ICRAM)

Via di Casalotti 300

00166 Roma, Italy

email: michela.angiolillo@isprambiente.it 